peasant community to support her claims. Berleant-Schiller and Maurer explore the blending rather than the separation of women's private and public roles in Dominica and Barbuda. Several essays in this section consider important Caribbean institutions in new ways. Pulsipher's paper on houseyards in Monteserrat shows how men's and women's places in domestic networks are spatially represented in the yard and how these roles shift over the life cycle. Brana-Schute traces the recent history of women's groups in Suriname, suggesting a mix of political and social functions, while raising questions about why women have not assumed more prominent and powerful political roles. Women's extensive obligations to kin, even after migrating, are explored by Olwig in an essay on women's intra-regional and international migration from Nevis.

The second half of the collection, on women in the economy, examines women's work in both rural and urban sectors. Contributions on women in rural economies generally point to women's historically extensive participation in farming. Papers on Barbados, Grenada, and Trinidad describe patterns of work, land control and crop selection. Stubbs' article on women's involvement in Cuban cooperative agriculture in relation to recent changes in political economy is especially interesting. Momsen's comparative analysis of women's farming and patterns of labor force participation in the eastern Caribbean also addresses structural economic changes in the region. Papers on women in the urban sector treat some new dimensions of women's work experience. Pearson's essay on gender and Jamaican information processing firms suggests that while national investment and control has increased industrial dynamism it will help women workers only if their technical abilities are acknowledged and easily transferred to better jobs. McKay's research on women and tourism in Negril, Jamaica, illustrates the constraints women marketers and landladies face from government regulation and from competition and control by men.

This collection is significant for its comprehensive scope and its rich empirical base. The second half of the book, on women in the economy, may be more successful in offering new information and ideas than the first, on the relationship of the public and private spheres. Momsen's Introduction and the precis to each section are acute; she could have offered further theoretical synthesis and more comparisons among societies without damaging the integrity of the empirical work. Essays on the English speaking West Indies significantly outnumber offerings on other areas. However, these problems do not diminish the value of the collection and its importance to the study of women and gender in the region.

\title{
This Fissured Land: An Ecological History of India. Madhav Gadgil and Ramachandra Guha. Berkeley: University of California Press, 1992. xiv, 274 pp.
}

\section{Reviewed by Sonja Brodt, Professor of Geography, University of Hawaii, Manoa Honolulu, HI 96822}

In a time of increasing polarity between North and South, first world and third world, over issues regarding natural resource use and management, Madhav Gadgil and Ramachandra Guha manage to move beyond the usual narrow, postcolonialist debates to construct a wider framework for analysis of Indian ecological problems in This Fissured Land: An Ecological History of India. Although not evident in the title, this book is 
specifically about the history of forest use in India, the understanding of which is enhanced by approaching forest management on two levels. On the one hand, the authors place it within the larger context of a conceptual framework that is broad enough to encompass a wide spectrum of resource use practices from hunter-gatherer to industrial modes. On the other hand, they narrow the scale of analysis by focusing on important details of Indian forestry that illustrate the larger concepts. Overall, This Fissured Land is a well-researched and clearly written book of relevance to cultural ecology and political ecology. It presents both a wealth of carefully chosen historical material and some useful thoughts on the origins of resource use problems and conflicts that are bound to stimulate debate.

The text is organized into three sections encompassing from one to five chapters each. In the first section the authors introduce a new theoretical framework for environmental history which they term "modes of resource use." This framework distills four basic resource use categories from human history: gathering (including shifting cultivation), nomadic pastoralism, settled cultivation, and industry. The authors admit from the outset that this framework is an "ideal type" (p. 13) and that not all societies may be so simply apportioned among its four categories. Given this disclaimer, the framework for the most part is illuminating. Occasionally, however, Gadgil and Guha devote too much effort to distinguishing one mode from another, with the result that they make a few questionable claims, such as that hunter-gatherers have a limited knowledge base and use only a small variety of resources. Such overdone statements could have been omitted without weakening the overall framework.

The authors' analytic approach is reminiscent of a Marxist "mode of production" framework, which they intend to complement. The main shortcoming of the Marxist approach, however, according to Gadgil and Guha, is its lack of reflection on ecological parameters, and they conclude on these grounds "that the mode of production concept is not adequately materialistic" (p. 12). This statement sets the tone for many subsequent chapters, which are written from a strongly materialistic perspective. Everything from economy to ideology is seen to derive from resource use modes. Some of the resultant ideas are intriguing, if somewhat debatable. For example, Hinduism, Buddhism, and Jainism are presented as arising in response to resource abundance or scarcity. Notwithstanding the fact that the focus of this book is on relationships between living resources and human society, the authors' failure to acknowledge the possibility of other influences on social formations--such as purely social and cognitive factors--is disconcerting.

Another prominent feature established in the first section and reminiscent of traditional cultural ecology is the repeated use of terms and concepts from biological ecology. For example, modes of resource use are compared to $r$ and $k$ strategies of different species. In a later section the caste system is interpreted simply as an ecological adaptation by which caste groups have come to occupy different resource "niches" according to Gause's principle of competitive exclusion. To a point, such analogies enrich the analysis by providing useful conceptual footholds. The danger, however, is that they disregard cognitive aspects of human behavior (see Ellen 1982).

The two latter sections of the book fill the theoretical framework established in the first with specifics of Indian forest management during the pre-colonial period and modern (colonial and postcolonial) times, respectively. Details are prudently compiled from an abundance of primary and secondary source material. This information alone would make the book worthwhile reading for any student of the history of Indian forest use. One of the 
most salient legacies of a Marxist approach evident in these sections is the focus on conflicts between different resource use modes. Refreshingly, Gadgil and Guha avoid dwelling at length on the usual, overused stories of conflict, such as that of the Chipko movement, and instead move quickly to lesser-known incidents which serve just as admirably to illustrate their points. They also avoid some of the black-and-white cliches so common in writings about colonial resource exploitation in the third world. For example, although British forestry policies are pinpointed as one major cause of forest depletion and conflicts, the authors also clearly demonstrate, often with direct quotes from colonial administrators' writings, that some of the administrators openly opposed the prevailing policies. They also decline to exonerate all Indian rulers, some of whose directives are shown to be more deleterious to forest dwellers and farmers than British policies. The result is an analysis that for the most part is refreshingly frank and balanced in its assessments.

Having detailed many problems in Indian forest use, the authors' closing remark that "it is too early to say" (p. 245) whether a new mode of resource use will prevail is initially disappointing. However, from the very first chapter Gadgil and Guha maintain that "given the complexity of ecological communities, precise prescriptions for the prudent use of living resources are difficult" (p. 23). Recognizing this complexity, they thus avoid the simplistic suggestions, such as that resource management should devolve entirely to local communities, that often conclude similar books. Finally, given the subtitle "ecological history," perhaps one should not expect solutions for the future to be explicitly laid out. Rather, it is ultimately contingent upon the reader to delve deeply into the historical analysis for any lessons it might hold.

Reference cited: Roy P. Ellen, Environment, Subsistence, and System: the Ecology of Small-Scale Social Formations. Cambridge: Cambridge University Press, 1982. pp. 89-93.

\title{
Orientalism and the Postcolonial Predicament: Perspectives on South Asia. By Carol A. Breckenridge and Peter van der Veer, editors. 1993. Philadelphia: University of Pennsylvania Press. viii, 355 pp.
}

\author{
Reviewed by James F. Fisher, Professor of Anthropology, Carleton College, \\ Northfield, Minnesota.
}

In 1978 Edward Said of Columbia University published a book, Orientalism, which created a sizable stir among humanists and social scientists concerned with the nonWestern world. Said argued unequivocally, and trenchantly, that western knowledge about the Orient was not just the product of disinterested scholarship, but "a systematic discourse by which Europe was able to manage--and even produce--the Orient politically, sociologically, militarily, ideologically, scientifically, and imaginatively." Orientalism, as he called this phenomenon, helped the West to control and exploit the Orient. Said, a Palestinian by origin, used the Mideast as his prime example of Orientalism, but he meant his sweeping claim to apply to all of the "Orient." 